\title{
Influence of Nitrogen and Sulphur Application on Yield and Quality of Soybean (Glycine max L.)
}

\author{
N. Mamatha ", K. Chandra Shaker, G. Padmaja and M. Malla Reddy \\ Department of Soil Science and Agricultural Chemistry, College of Agriculture, Prof. \\ Jayashanker Telangana State Agricultural University, Rajendranagar, \\ Hyderabad-030, Telangana State, India \\ *Corresponding author
}

\section{A B S T R A C T}

\begin{tabular}{|l|}
\hline Ke y w o r d s \\
$\begin{array}{l}\text { Nitrogen, Sulphur, Yield, } \\
\text { Oil content, Protein } \\
\text { content, Soybean }\end{array}$ \\
\hline Article Info \\
\hline $\begin{array}{l}\text { Accepted: } \\
24 \text { May } 2018 \\
\text { Available Online: } \\
\text { 10 December } 2018\end{array}$ \\
\hline
\end{tabular}

\section{Introduction}

Soybean (Glycine $\max$ L. Merrill), is an introduced and commercially exploited crop in India. It has highest protein $40 \%$, oil $20 \%$, rich in lysine and vitamins $\mathrm{A}, \mathrm{B}$ and $\mathrm{D}$ and also rich in mineral salts. Soybean is preferable for human nutrition due to its high protein content and it is a good source of isoflavones and therefore it helps in preventing heart diseases, cancer. Soybean oil is the leading vegetable oil in the world and is used in many industrial applications including biodiesel. The crop is called as "Golden Bean" or "Miracle crop" of the 21st century because of its high nutritional value and myriad form of uses. Soybean was grown in a small way for the past many decades in India, but since 1972 the area sown to the crop has increased substantially. Currently, in India area under soybeans is grown in $11.60 \mathrm{~m}$ ha with a production of 10.91 million tones and productivity of $738 \mathrm{~kg} \mathrm{ha}^{-1}$ (Directorate of Economics and Statistics, 2015-16).

Nitrogen and sulphur plays an important physiological and biochemical role in plants, nitrogen is a major essential plant nutrient element. It has the quickest and most pronounced effect on plant growth and yield of crops. It tends primarily to encourage above ground vegetative growth and to impart deep 
green colour to the leaves. In all plants, nitrogen governs a considerable degree of utilization of potassium, phosphorus and other nutrients. Plants receiving insufficient nitrogen are stunted in growth with restricted root systems. The leaves turn yellow or yellowish green and tend to drop off.

Sulphur is one of the essential nutrient required for the plant growth. It is now assuming importance next to the major nutrients i.e., nitrogen, phosphorus and potassium. Intensive cultivation with high yielding varieties, use of high analysis NPK fertilizers and limited manuring have resulted in emergence of secondary and micronutrient deficiencies in soils. Among secondary nutrients, deficiency of sulphur (S) was reported (Tiwari). Sulphur deficiency in soils of Indian states varies from 5 to 83 per cent with overall mean of 33 to 41 per cent 16 .

Lack of sulphur in soil limits the efficiency of added nitrogen in the soils, therefore, sulphur addition become necessary to achieve the maximum efficiency of added nitrogenous fertilizers. The optimum ratio of available $\mathrm{N}$ to the available $S$ to be $7: 1$, the ratio below 7 gives reduced seed yield. The larger dose of gypsum reduces the yield when nitrogen status in soil is unsatisfactory and shortage of sulphur to crops lowers the utilization of available nitrogen.

\section{Materials and Methods}

In order to study the effect of nitrogen and sulphur levels on yield, protein and oil content of soybean an experiment was conducted during kharif, 2017 at College Farm, Agricultural College, Polasa, Jagtial, Professor Jayashankar Telangnana State Agricultural University. The experiment was laid out in randomized block design with factorial concept (FRBD) with three replications. Four levels of nitrogen viz., 0, 40, 80, $120 \mathrm{~kg} \mathrm{~N} \mathrm{ha}^{-1}$ and four levels of sulphur viz., 0, 20, 30 and $40 \mathrm{~kg} \mathrm{ha}^{-1}$ were adopted, thus a total of 16 treatments were imposed. Soybean variety JS335 was used for the study. The soil of the experiment site was sandy loam in texture, having neutral in reaction ( $\mathrm{pH} 7.26)$, normal in salinity (EC $0.03 \mathrm{~d} \mathrm{Sm}^{-1}$ ), low in organic carbon content $(0.34 \%)$, available $\mathrm{N}(126 \mathrm{~kg}$ $\mathrm{ha}^{-1}$ ), available phosphorus (20.6 $\mathrm{kg} \mathrm{ha}^{-1}$ ), medium in available potassium (180.2 $\mathrm{kg} \mathrm{ha}^{-1}$ ) and deficient in available sulphur $\left(9.2 \mathrm{mg} \mathrm{kg}^{-}\right.$ $\left.{ }^{1}\right)$. Recommended dose of $\mathrm{P}$ and $\mathrm{K}(60 \mathrm{~kg}$ $\mathrm{P}_{2} \mathrm{O}_{5}$ and $40 \mathrm{~kg} \mathrm{~K} 2 \mathrm{O}$ ) were applied to all plots in the form of DAP and MOP. Nitrogen and elemental sulphur were applied to the respective plots as per treatment requirement.

Protein content in seed was estimated by Lowry method (Sadasivam and Manickam, 1996) and protein yield was calculated by multiplying the protein content in each treatment with corresponding seed yield. Oil content was determined by Nuclear Magnetic Resonance (NMR) spectrophotometer and expressed as percentage (Sambunatham et al., 1985). Oil yield was calculated by multiplying the oil content $(\%)$ in each treatment with corresponding seed yield as given as

Oil content (\%) X Seed yield $\left(\mathrm{kg} \mathrm{ha}^{-1}\right)$ Oil yield $\left(\mathrm{kg} \mathrm{ha}^{-1}\right)=$

100

\section{Results and Discussion}

\section{Yield}

Significant variation on haulm and seed yield of soybean was observed from different nitrogen and sulphur levels. Among the nitrogen levels, the highest haulm and seed yields (3069 and $1977 \mathrm{~kg} \mathrm{ha}^{-1}$ ) were recorded with the application of $120 \mathrm{~kg} \mathrm{~N} \mathrm{ha}{ }^{-1}\left(\mathrm{~N}_{3}\right)$, whereas, lowest haulm and seed yields (2031and $1399 \mathrm{~kg} \mathrm{ha}^{-1}$ ) were recorded in control $\left(\mathrm{N}_{0}\right)$. The mean seed yield was 
increased by $21.0,40.0$ and 42.7 per cent by the application of $40\left(\mathrm{~N}_{1}\right), 80\left(\mathrm{~N}_{2}\right)$ and 120 $\left(\mathrm{N}_{3}\right) \mathrm{kg} \mathrm{N} \mathrm{ha}^{-1}$, respectively as against control $\left(\mathrm{N}_{0}\right)$ which recorded the lowest mean seed yield. The increase in haulm and seed yield might be due to continuous supply of nitrogen during crop growth and important role played by nitrogen in energy transformations, activation of enzymes in carbohydrate metabolism and consequently greater transformation of photosynthates into reproductive parts. These results are in line with the findings of Sikka et al., (2013) and Mohanyadravi and Angadi, (2016) who reported that application of higher doses of nitrogen to soybean recorded significantly higher seed yield compared to control plot (Table 1).

Similarly, application of graded levels of sulphur significantly increased the haulm and seed yield of soybean. Increasing the sulphur levels increased the haulm yield up to application of $20 \mathrm{~kg} \mathrm{~S} \mathrm{ha}^{-1}\left(\mathrm{~S}_{1}\right)$. Application of sulphur at the rate of $20 \mathrm{~kg} \mathrm{ha}^{-1}$ recorded maximum haulm yield of $2675 \mathrm{~kg} \mathrm{ha}^{-1}$, it was comparable with the treatments receiving 30 $\left(\mathrm{S}_{2}\right)$ and $40\left(\mathrm{~S}_{2}\right) \mathrm{kg} \mathrm{S} \mathrm{ha}{ }^{-1}$ and lowest was recorded in control $\left(2397 \mathrm{~kg} \mathrm{ha}^{-1}\right)$. The mean seed yield of $1977 \mathrm{~kg} \mathrm{ha}^{-1}$ was recorded with the application of $120 \mathrm{~kg} \mathrm{~N} \mathrm{ha}^{-1}$ and it was significantly superior over control $\left(\mathrm{N}_{0}\right)$ and 40 $\mathrm{kg} \mathrm{N} \mathrm{ha}^{-1}\left(\mathrm{~N}_{1}\right)$, and statistically on par with the application of $80 \mathrm{~kg} \mathrm{~N}^{-1}\left(\mathrm{~N}_{2}\right)$. The mean seed yield was increased by 21.0, 40.0 and 42.7 per cent by the application of $40\left(\mathrm{~N}_{1}\right), 80$ $\left(\mathrm{N}_{2}\right)$ and $120\left(\mathrm{~N}_{3}\right) \mathrm{kg} \mathrm{N} \mathrm{ha}^{-1}$, respectively over control $\left(\mathrm{N}_{0}\right)$. The increase in haulm and seed yield of soybean might be due to continuous supply of nitrogen during crop growth and important role played by nitrogen in energy transformations, activation of enzymes in carbohydrate metabolism and consequently greater transformation of photosynthates into reproductive parts. These results are in line with the findings of Sikka et al., (2013) and
Mohanyadravi and Angadi, (2016) who reported that application of higher doses of nitrogen to soybean recorded significantly higher seed yield compared to control plot.

The interaction effect of nitrogen and sulphur levels had no influence on haulm yield of soybean and it was significant in increase the seed yield of soybean from $1374 \mathrm{~kg} \mathrm{ha}^{-1}$ in control to $2160 \mathrm{~kg} \mathrm{ha}^{-1}$ obtained due to the combined application of $120 \mathrm{~kg} \mathrm{~N}$ and $40 \mathrm{~kg} \mathrm{~S}$ $\mathrm{ha}^{-1}\left(\mathrm{~N}_{3} \mathrm{~S}_{3}\right)$. This is because of synergistic effect of $\mathrm{N}$ and $\mathrm{S}$ in producing the higher yield. These findings are in conformity with those of Jamal et al., (2005), Sharma et al., (2014), Anil et al., (2017).

\section{Protein content and protein yield}

Seed protein content and protein yield was significantly influenced by different nitrogen levels (Table 2). Application of nitrogen at $120 \mathrm{~kg} \mathrm{ha}^{-1}\left(\mathrm{~N}_{3}\right)$ recorded the highest protein content and protein yield against control $\left(\mathrm{N}_{0}\right)$. These results are conformity with the findings of Kushwaha and Chandel (1997) who reported that application of $150 \mathrm{~kg} \mathrm{~N} \mathrm{ha}^{-1}$ increased the protein content in case of soybean. Increase in protein content of soybean with increasing levels of $\mathrm{N}$ was also reported by Morshed et al., (2008), Kumawat et al., (2000).

Similar to nitrogen, sulphur levels also had a significant effect on protein content and protein yield of soybean. The protein content of the seed increased significantly from a mean value of 37.77 per cent at control $\left(\mathrm{S}_{0}\right)$ level to 38.48 per cent at $S_{30}$ level which was on par with $S_{40}$. It may be because sulphur is the key constituent of essential amino acids like methionine, cysteine and cystine which are the precursors for protein synthesis. The above results are in conformity with reports of Hari ram et al., (2014), Singh et al., (2013). 
Table.1 Effect of nitrogen and sulphur on haulm and seed

\begin{tabular}{|c|c|c|}
\hline Treatment & Haulm yield $\left(\mathrm{kg} \mathrm{ha}^{-1}\right)$ & Seed yield $\left(\mathrm{kg} \mathrm{ha}^{-1}\right)$ \\
\hline $\mathbf{N}_{0}$ & 2031 & 1400 \\
\hline $\mathbf{N}_{1}$ & 2565 & 1693 \\
\hline $\mathbf{N}_{2}$ & 2945 & 1961 \\
\hline $\mathbf{N}_{3}$ & 3069 & 1997 \\
\hline $\mathrm{CD}$ & $\mathbf{2 6 9}$ & $\mathbf{1 7 7}$ \\
\hline $\mathbf{S}_{0}$ & 2397 & 1623 \\
\hline $\mathbf{S}_{1}$ & 2675 & 1756 \\
\hline $\mathbf{S}_{2}$ & 2680 & 1799 \\
\hline $\mathbf{S}_{3}$ & 2858 & 1874 \\
\hline $\mathrm{CD}$ & $\mathbf{2 6 9}$ & $\mathbf{1 7 7}$ \\
\hline Interaction NXS & & $\mathbf{3 5 3}$ \\
\hline $\mathbf{C D}$ & $\mathbf{N S}$ & $\mathbf{1 2}$ \\
\hline $\mathbf{C V}$ & $\mathbf{1 2 . 2}$ & \\
\hline
\end{tabular}

Table.2 Effect of nitrogen and sulphur on quality of soybean

\begin{tabular}{|c|c|c|c|c|}
\hline Treatment & $\begin{array}{c}\text { Protein } \\
\text { Content }(\%)\end{array}$ & $\begin{array}{c}\text { Oil content } \\
(\%)\end{array}$ & $\begin{array}{c}\text { Protein yield } \\
\left(\mathrm{kg} \mathrm{ha}^{-1}\right)\end{array}$ & $\begin{array}{c}\text { Oil yield } \\
\left(\mathrm{kg} \mathrm{ha}^{-1}\right)\end{array}$ \\
\hline $\mathbf{N}_{0}$ & 35.6 & 17.24 & 498 & 241 \\
\hline $\mathbf{N}_{1}$ & 37.4 & 18.13 & 634 & 307 \\
\hline $\mathbf{N}_{2}$ & 39.5 & 18.62 & 777 & 367 \\
\hline $\mathbf{N}_{3}$ & 40.3 & 18.65 & 805 & 372 \\
\hline $\mathrm{CD}$ & $\mathbf{0 . 6 1}$ & $\mathbf{0 . 7 1}$ & $\mathbf{6 9 . 1 2}$ & $\mathbf{3 8 . 5}$ \\
\hline $\mathbf{S}_{0}$ & 37.7 & 17.84 & 616 & 290 \\
\hline $\mathbf{S}_{1}$ & 37.89 & 18.18 & 670 & 320 \\
\hline $\mathbf{S}_{2}$ & 38.48 & 18.24 & 697 & 330 \\
\hline $\mathbf{S}_{3}$ & 38.74 & 18.38 & 731 & 346 \\
\hline CD & $\mathbf{0 . 6 1}$ & $\mathbf{N S}$ & $\mathbf{6 9 . 1 2}$ & $\mathbf{3 8 . 5}$ \\
\hline Interaction & & & & \\
\hline NXS & & $\mathbf{N S}$ & $\mathbf{N S}$ & $\mathbf{N S}$ \\
\hline CD & $\mathbf{N S}$ & $\mathbf{4 . 6 7}$ & $\mathbf{1 2 . 2}$ & $\mathbf{1 4 . 3 7}$ \\
\hline CV & $\mathbf{1 . 9 0}$ & & & \\
\hline
\end{tabular}

The increase in seed protein content of soybean with the application of $\mathrm{N}$ and $\mathrm{S}$ might be due to the fact that $\mathrm{N}$ is the integral part of protein and protein of oil seeds contain relatively higher quantity of $\mathrm{S}$ containing amino acids (methionine and cystine and cystene). The increase protein content with increase in $\mathrm{N}$ and $\mathrm{S}$ rates confirmed with the findings of Aulakh (1995) who found that application of $\mathrm{N}_{100} \mathrm{~S}_{20}$ recoded highest protein content. Interaction effect of nitrogen and sulphur was found to be non-significant in increasing the protein content of soybean.

\section{Oil content and oil yield}

The mean oil content and oil yield of soybean was significantly increased from 17.24 
percent and $241 \mathrm{~kg} \mathrm{ha}^{-1}$ at $\mathrm{N}_{0}$ level (control) to 18.65 percent and $372 \mathrm{~kg} \mathrm{ha}^{-1}$ due to the application of $120 \mathrm{~kg} \mathrm{~N} \mathrm{ha}^{-1}\left(\mathrm{~N}_{3}\right)$. Nitrogen can increase oil content in seed via increasing vegetative growth and higher production of carbohydrate in plant and transferring to seeds (Hasanzade, 2002). The results are in agreement with those of reported by Jahangir et al., 2009 who observed that there was an increased trend of oil percentage in soybean by nitrogen fertilizer application.

Increasing levels of sulphur application did not influenced the oil content of soybean. But the oil content was progressively increased with increasing levels of sulphur application. Application of sulphur from 0 to $40 \mathrm{~kg} \mathrm{ha}^{-1}$ tends to increase the mean oil yield of soybean from 290 to $346 \mathrm{~kg} \mathrm{ha}^{-1}$. The increase in oil content with addition of sulphur might be associated with direct involvement of sulphur in the synthesis of lipids, in fatty acid synthesis acetyl-CoA enzyme activity (Ahmad et al., 2000). In this conversion an enzyme thiokinase is involved in sulphur supply, moreover, acetyl Co- enzyme itself contain sulphur and sulpho-hydryl groups. These results are in accordance with Venugopal et al., (2017), Hariram et al., (2014), Choudhary et al., (2014). Interaction effect of nitrogen and sulphur found to absent in oil content and oil yield of soybean.

\section{References}

Anil, D., Vidya Sagar, G. E. CH., Sreenivasand, G and Sharma, H. K. S. 2017. Effect of sulphur and nitrogen application on growth characteristics and yield of soybean (Glycine $\max (\mathrm{L}$.) Merrill). International Journal of Pure and Applied Bio science. 5 (4): 1548 1554.

Aulakh, M. S., Pasricha, N. S and Ahuja, K. L. 1995. Effect of nitrogen and sulphur application on grain and oil yields, nutrient uptake and protein content in transplanted gobhi sarson (Brassica napus subsp oleifera var annua). Journal of Agricultural Reseasrch. 65 (7): 478- 482.

Choudhary, P., Jhajharia, A and Kumar, R. 2014. Influence of sulphur and zinc fertilization on yield, yield components and quality traits of soybean [Glycine $\max (\mathrm{L}$.$) Merrill]. The Bioscan. 9$ (1): 137-142.

Hari Ram, Singh, G and Aggarwal, N. 2014. Grain yield, nutrient uptake, quality and economics of soybean (Glycine max) under different sulphur and boron levels in Punjab. Indian Journal of Agronomy. 59 (1): 101-105.

Hasanzade, A. 2002. The effect of different amounts of Nitrogen fertilizer on yield and yield component and grain oil of sunflower. Uremia Agricultural Science Research. 2 (1): 25-33.

Jahangir, A. A., Mondal, R. K., Nada, K., Sarker, M. A. M., Moniruzzaman, M and Hossain, M. K. 2009. Response of different level of nitrogen and phosphorus on grain yield, oil Quality and nutrient uptake of soybean. Bangladesh Journal of Scientific and Industrial Research. 44 (2): 187-192.

Jamal, A., Fazli, I. S., Ahmad, S., Abdin, M. $\mathrm{Z}$ and Yun, S. J. 2005. Effect of sulphur and nitrogen application on growth characteristics, seed and oil yields of soybean cultivars. Korean Journal of Crop Science. 50 (5): 340-345.

Kushwat, H. S and Candel, A. S. 1997. Effect of nitrogen on yield, yield attributes and quality of soybean intercropped with cereals in foot-hills of Uttar Pradesh. Indian Journal of Agronomy. 42 (3): 409-413.

Mohan yadravi and Angadi, V. V. 2016. Effect of time and method of application of varied levels of nitrogen 
in soybean (Glycine max). Journal of Farm Science. 29 (3): 332-336.

Morshed, R. M., Rahman M. M and Rahman, M. A. 2008. Effect of nitrogen on seed yield, protein content and nutrient uptake of soybean (Glycine max L.). Journal of Agriculture and Rural Development. 6 (1\&2): 13-17.

Sharma, A., Sharma, S and Gill, P.P.S. 2014. Influence of nitrogen and sulphur application on nutrient uptake, protein content and yield parameters of soybean. Indian Journal of Plant Sciences. 3 (2): 31-34.

Sikka, R., Singh, D and Deol, J. S. 2013. Productivity and nutrient uptake by soybean as influenced by integrated nutrient and some other agronomic management practices. Legume Research. 36 (6): 545- 551.

Tiwari, R. J., 2006, Response of sugarcane (Saccharum officinarum) to direct and residual effect of sulphur. Indian Journal of Agricultural Science. 76 (2): 117-119.

Venugopal, G., Sharma, S.H.K., Qureshi, A.A., Vidya Sagar G.E.Ch and Bhave, M.H.V. 2017. Effect of sulphur levels and poultry manure on crop performance of soybean (Glycine max L.). International Journal of Pure and Applied Siol Science. 5 (4): 1599-1605.

\section{How to cite this article:}

Mamatha, N., K. Chandra Shaker, G. Padmaja and Malla Reddy, M. 2018. Influence of Nitrogen and Sulphur Application on Yield and Quality of Soybean (Glycine max L.). Int.J.Curr.Microbiol.App.Sci. 7(12): 3452-3457. doi: https://doi.org/10.20546/ijcmas.2018.712.393 